\title{
XIST wt Allele
}

National Cancer Institute

\section{Source}

National Cancer Institute. XIST wt Allele. NCI Thesaurus. Code C75595.

Human XIST wild-type allele is located in the vicinity of Xq13.2 and is approximately $32 \mathrm{~kb}$ in length. Rather than encoding a protein, this allele appears to encode a structural RNA which may play a role in female dosage compensation of the $\mathrm{X}$ chromosome. 